Pakistan Journal of Humanities and Social Sciences
Volume 9, Number 1, 2021, Pages $\mathbf{3 9}-\mathbf{5 0}$

\title{
Exploring E-Commerce and Corporate Social Responsibility from the Sharia Point of View
}

Mohammad Faruk Hossain ${ }^{1}$, Che Thalbi bt Md. Ismail ${ }^{2}$, Nazli Mahdzir ${ }^{3}$

1, 2, 3 School of Law, Ghazali Shafie Graduate School of Government, Universiti Utara Malaysia, Sintok-06010, Malaysia

\begin{tabular}{|c|c|c|}
\hline \multicolumn{2}{|l|}{ ARTICLE INFO } & \multirow{2}{*}{$\begin{array}{l}\text { ABSTRACT } \\
\text { This study discusses what is, and what is not a valid and legal } \\
\text { contract in Sharia, considering certain stipulated requirements for } \\
\text { the acceptability of a contract. It then considers the legality of e- } \\
\text { commerce, whether it complies with those stipulated requirements. } \\
\text { Business under Islam primarily fulfils a collective religious } \\
\text { obligation and fulfil an enlarged scope of responsibilities. In this }\end{array}$} \\
\hline & & \\
\hline \multicolumn{2}{|c|}{$\begin{array}{l}\text { Keywords: } \\
\text { E-Commerce } \\
\text { Contract } \\
\text { Issue, Data } \\
\text { Sharia } \\
\text { Corporate Social Responsibility }\end{array}$} & $\begin{array}{l}\text { context, the protection of the e-consumers, the status of an e- } \\
\text { commerce transaction and responsible e-commerce are discussed } \\
\text { to expose to those who are wondering whether e-commerce is } \\
\text { admissible from the Sharia point of view. So that they could benefit } \\
\text { from e-commerce if it is proved as an admitted fact in Islam. The } \\
\text { final section concludes with a plea for good judgment toward } \\
\text { corporate social responsibility practice and avoiding prohibited }\end{array}$ \\
\hline & & \\
\hline
\end{tabular}

G34, K12, L81, M14, M19

(c) 2021 The Authors, Published by iRASD. This is an Open Access Article under the Creative Common Attribution Non-Commercial 4.0

Corresponding Author's Email: lawyerfaruk@gmail.com

\section{Introduction}

Trade and commerce are significant parts of the Islamic legal system (Sharia) and business ethics (Amboala et al., 2015). Islam accedes to the importance of the business sector. Islam considers business as a resource of wealth and recommends business and trade. It is fair to say business lies in the heart of Islam (Azizan \& Wahid, n.d.). Business accelerates the development of the nation (Amboala et al., 2015). Islamic history exemplifies that business is conducive and supportive to the merchant, beginning with successful merchants Prophet Mohammad (SWT) and his wife Khadijah (Azizan \& Wahid, n.d.).

Throughout the Holy Quran, several verses mention that most of the sustenance of mankind (9 over 10) came from business activity (Azizan \& Wahid, n.d.). Sharia ruling of business emphasizes benefiting society as well as humanity while conducting business and maintaining Allah's (SWT) order (S. F. Ahmad, 1991). The Holy Quran consists of principles and guidance about every aspect of life together with business activities (Amboala et al., 2015), which apply to all times and places (Zainul et al., 2004).

Muslims are wondering to a depth understanding about a newly born business concept that features a similar definition to the traditional business, but the settings are different (Zainul et al., 2004). Electronic commerce (e-commerce, as it is widely known) is a newly born business concept. In the field of business, it is a revolutionary invention powered by communication and information technology (IT) (Nanehkaran, 2013). It has fundamentally changed the form and appearance of traditional business and the current of human life. Ecommerce systematically processes buying and selling goods and services electronically via smart device and network system (Laudon \& Laudon, 2000). At present, customers can access virtual stores to browse through, and place orders for products or services via electronic devices on the go (Zainul et al., 2004). Due to such immense benefits for human e-commerce is spreading remarkably (Nanehkaran, 2013).

Muslims believe the fundamental teaching of Islam derives from the Holy Quran, Sunnah (the practice of Holy Prophet (SWT)), Ijma (wisdom) and Qiyas (consensus of religious scientist) (Zainul et al., 2004). Within the Muslim nation (Ummah), a public belief exists that 
the code of conduct of human life including business activity is pre-identified by the divine law (Amboala et al., 2015). For every new issue, Muslim prioritise and rely on the divine laws to justify the merit and permissibility to protect their faith and religious obligations. To date, the status of e-commerce is unsettled to many Muslims who want to know e-commerce considering the Sharia (Zainul et al., 2004). Therefore, this effort is designed to examine the Sharia perspectives of e-commerce.

Addressing the facet, the study will focus on academic and Islamic juristic works to analyse both the technical and the legal characteristics of e-commerce in terms of Sharia. So, worldwide Ummah could gain from this new business mechanism if Islam admits e-commerce. This study is significant for Muslim since Islam stresses seeking both divine and worldly knowledge. The Holy Quran says in the first revelation "Iqraa, or Read! or Proclaim! or Alaq, or The Clot of Congealed Blood. In the name of Allah, Most Gracious, Most Merciful. Proclaim! (or Read!) in the name of thy Lord and Cherisher, Who Created man, out of a (mere) clot of congealed blood" (Ali, 2016, vv. 96:1-2).

This study presents a theoretical view on e-commerce in Sharia (Islamic law) where it employs library research using both classical and contemporary works of literature. In Section 2 , the study starts with a literature review where it defines e-commerce, Section 3 discusses Sharia rules regarding a commercial contract, Section 4 covers the legal issues of e-commerce, Section 5 covers various types of e-commercial contract, Section 6 covers e-commerce payment, Section 7 covers e-commerce protection issues, Section 8 covers corporate social responsibility practice considering Sharia-compliance materials, Section 9 covers some ecommercial imperative issues followed by recommendation, and the last section is the conclusion followed by research references.

\section{What is E-Commerce?}

The executive editor of the International Journal of Electronic Commerce, Zwass (2001) says "E-commerce describes sharing business information, maintaining business relationships and conducting business transactions using telecommunications networks." Management expert Turban et al. (2002) says "E-commerce means the process of buying, selling, transferring, or exchanging products, services and/or information via the computer network, including the internet." Whiteley (2000) provides a wider concept that "Any form of the business transaction executed using information and communication technology (ICT) is an ecommerce." Brunn \& Leinbach (2001) explain "The use of information and communication technologies to network economic activities and processes, to decrease information related to transaction costs to advance a strategic information advantage."

The scholarly discussion above points that e-commerce is an online commercial transaction. Whenever someone buys or sells something, i.e. goods or services using the online platform, he/she is in e-commerce. E-commerce is an effort where contracting parties are free from physical meeting session to negotiate the terms of the contract (Muhammad et al., 2013). Timmers (2000) provides a clear-cut definition in this regard that makes a better understanding "E-commerce is about doing business electronically." Meaning that e-commerce is a form of business action with the support of the network technology that connects the seller, the buyer and other relevant parties (Amboala et al., 2015).

The convergence of technology and commerce has made it possible to conduct every sort of business activity and enabled buy or sell anything from distance (Amboala et al., 2015). King \& King (2004) support this view and, in their book "Introduction to e-commerce" opine that with the onset of the Internet, the term e-commerce initiated to involve everything of trade (i.e., marketing, ordering, payment, delivery, etc.) and added more features, such as trading of intangible goods (i.e., information, consultancy, support, etc.).

The current world has seen a significant major change in the business world shifted from intrinsic form to a virtual. Such advancement has brought a more complex level of Islamic business and commerce ethics (Amboala et al., 2015). Whilst e-commerce is spreading worldwide, there are significant confusions whether this new approach of commerce is admitted and accepted as per Sharia. Issues initially raise regarding the legality of e- 
commerce contract in Sharia. The following discussion is an attempt to address the legal standards of an e-commerce contract considering the Sharia norms.

\section{The Contract in Sharia}

The term contract is synonymous with Aqd in classical literature of figh (the Islamic jurisprudence), which means to conclude or to tie. It is a combination of offer and acceptance between contracting parties that constitute a legal obligation on them (Rosly, 2010). The Sharia (Islamic law) of contracts primarily objects to protecting interests and eliminating harms of parties (Mohammed, 1988). Sharia demonstrates that a valid contract consists of several significant prescribed elements, without them a contract must lose its merit to be valid (Esposito \& DeLong-Bas, 2018). These elements have been developed throughout the Islamic civilization based on the needs and requirements of society (Mohammed, 1988). This study now moves on to explain the main three (3) elements of a legally binding contract per Sharia i.e., the form (offer, acceptance and consideration), the subject matter and the contracting parties.

Sharia signifies offer, acceptance and consideration for a valid contract. A valid contract involves a verbal or written expression that signifies authority or keenness of its doer, which assumed from the proposal first offered by one of the contracting parties. The other party represents a declaration of acceptance indicating recognition of that proposal with consideration (Amin, 2008). Consideration, "i.e., quid pro quo or something is given for something received" is crucial for a contract. It is the base statement that represents what is being exchanged among the parties as consideration (i.e., a specific purchase price or payment in exchange for specific goods or services). However, such an offer or acceptance comes from the mutual consent of the parties. Without a wilful mutual acknowledgement, a contract is out of legal consequence. Free will to make a contract is essential because a contract is invalid where coercion or any other factors result in such consent of the parties (Amin, 2008). The Holy Quran priorities mutual consent. The Holy Prophet (SWT) warns that "Sale is but based on mutual consent" (as cited in Muhammad et al., 2013).

Sharia also signifies that a valid contract represents a subject matter that is something property or wealth that is usable at the time of need. Under Sharia, property refers to an object which has a practicable existence in the outside world. The Holy Prophet (SWT) said "Do not sell what you do not have" (as cited in Muhammad et al., 2013). A valid contract involves lawfulness, existence, deliverability and precise determination of the property. Illegal, nonexistence of subject matter, the uncertainty of delivery, in-determination to its essence, quality and value are contradictory to a valid contract. In the case where someone mediates the selling on behalf of others, he needs proper approval to deal on behalf of the owner of the subject matter (Al-'Ajluni, 2002).

Sharia strongly signifies the legal competency of the parties (offeror and offeree) to make a contract (Saleem, 2012). The Holy Quran hints at prudence and puberty as the competency measurement tools of a party intended to make a contract. The Quranic verse demonstrates the possess capacity of each party as the significant factor. It is the quality of a person that qualifies for obtaining rights and carrying out responsibilities and duties. The Holy Quran says "Make trial of orphans until they reach the age of marriage; if then ye find sound judgment in them, release their property to them" (Ali, 2016, v. 4:6). A valid contract under Sharia ensures the capacity of the parties to obtain rights and related advantages and to simplify the obligation upon them. A legal and valid contract ensure the physical and intellectual maturity of the parties. Because the capacity to make contract questions contractual rights and obligations.

These are the core elements and prerequisites of a valid contract in Sharia. The next discussion will go deep into the e-commercial contractual elements to analyse the validity from the Sharia point of view. The following study is worthy to know whether the e-commercial contractual elements are in line with the Sharia principles that may remove the legality issues regarding contract.

\section{Legality Issues of E-Commerce}

Conceptually e-commerce and common business are of a similar kind. E-commerce conveys the same meaning as that of traditional commerce in Islam (Turban et al., 2002). A 
study, namely, "E-commerce from an Islamic perspective" by Zainul et al. (2004) reveals that the Holy Quran hints at two purpose-built preconditions for the validity of any deal such as permissibility and harmlessness. The subject matter of the deal requires permissibility standards according to Sharia. The purpose and merit of any dealing and its elements must not be destructive to the parties or even the common people. Sharia accepts every initiative that makes something good, pure and wholesome for all. No matter whether it is a traditional business platform or electronic, Sharia looks first at these two (2) prerequisites as the basic standards and then the characterised requirements (Zainul et al., 2004).

In a traditional commercial setting, the seller presents the product, price, and terms to the potential buyer. The buyer makes payments against the purchase order upon considering available benefits and delivery of the product (Muhammad et al., 2013). E-commerce is not distinct from this concept. The e-commercial offer starts when the seller electronically displays the details of the products i.e. the price, payment facilities, delivery and then seeks concernment of the offeree by the "accept" or "agree" option. The acceptance is commenced when the buyer communicates with the seller via selecting that "accept" or "agree" option and proceed with the purchase (Al-Zahrani, 2009).

The study reveals that in e-commerce an offer and acceptance toward a contract may occur by two means (Al-Zahrani, 2009; Alzaagy, 2007). In some cases, parties are present in the virtual platform and express interest to each other via a short message service (SMS) or other electronic communication services. Upon communication and discussion via chatting or similar method, both parties agree to enter into a contract of sale and perform their duties and responsibilities (Muhammad et al., 2013). In another scenario, there is no direct physical or virtual communication between the parties unless knowing details from the network-based platform on the electronic device's screen. The communication medium provided on that platform such as website, email allows both parties to agree on that selective matter and both acquire rights and undertake duties and responsibilities thereon (Muhammad et al., 2013).

Regarding offer and acceptance in e-commerce, scholars argue as to the meeting session of the parties. Some scholar opines that an offer starts immediately once a seller publishes advertisement to sell products on the electronic network platform such as the website (Al-'Ajluni, 2002; Al-Momani, 2004; Haqqi, 1999). Some other scholars argue this view and opine that; an e-commercial offer starts only once a buyer check-out the product in details and proceeds with the approval for the next step such as payment. And the payment for the selected item is the acceptance of that offer (Al-Zahrani, 2009; Alzaagy, 2007).

As to the validity of an e-commercial offer and acceptance toward a contract, Islamic scholar opines that; the e-commercial contract is valid and binding. E-commercial dealing fulfils the requirements of conformity of the offer, acceptance and consideration as mentioned above (Al-Zahrani, 2009). There might have minor variation in the different platform, but mostly they do not substantially affect the validity from the Sharia viewpoint as they comply with the Sharia of contract (Muhammad et al., 2013).

In Islam, a business contract concludes with the delivery of the product being traded. e-commerce guarantees delivery of the traded item within a stipulated timeframe. Delivery of the product may occur either through shipping or downloading where the item is a digital media product such as software, eBooks, and similar. As a broker e-commerce receives the payment itself and waits for the delivery confirmation for securing the buyer. Unless gold, the delivery of every e-commerce item is Sharia-compliant and secured. Sharia requires a handto-hand exchange of gold (Lokmanulhakim et al., 2012). In term of delivery of the product, ecommerce is valid since it secures delivery.

E-commercial subject matter consists of written description and relevant photos that enable precise proof of identity, category and quantity. Allocating a distinct webpage for each item, the e-commerce platform provides details with a descriptive display of the item or threedimensional views to prevent uncertainty and ignorance. The supplemental product information like manufacturers specifications, comments, and rate from the customer who has been purchased the products are also trackable to justify that remove all the vagueness of a product posted on the e-commerce platform. The price and the delivery terms enable the 
buyer to think about the product before proceeding to purchase. Hence, e-commerce is valid in terms of subject matter as it discloses all the relevant information which enables the buyer to consider as per freewill (Zainul et al., 2004).

In term of the legal capacity of the parties in e-commerce, the credit card or the debit card proves the legitimacy of the parties. One may create an account in an e-commerce platform, but whenever he/she wants to proceed to a buy or sale he/she needs to supply debit or credit card details (Amboala et al., 2015). The ability to possess the card turns into proof of eligibility and legal capacity. Hence, in term of the legal capacity of the party e-commerce complies with the Islamic law of contract.

\section{E-Commercial Contract}

After discussing the elements of a valid contract, this study moves on to explain the nature of an e-commercial contract, because there are various types of contracts practised in business and financial transactions (Mohammed, 1988). It is, therefore, worth studying whether the e-commercial contract is in line with the Sharia. If a contract contradicts to fundamental rules of Sharia, then it is prohibited. And if it is found not in line with the Sharia rule but modifiable then it needs modification and filtering from forbidden elements (Saleem, 2012). For instance, riba (interest) and gambling-based contracts are prohibited. They contradict the fundamental principles of Sharia.

In Islam, there are various forms of contract distinct from each other. Islam allows a contract of sale where one pays fully in advance and wait for the delivery of the product in the future. Such a contract is known as Ordered-Sale (Bai' Al-Salaam) (Ahmad, 2001). The Quranic verse and Hadith of the Holy Prophet (SWT) declare Ordered-Sale is legal. Ibn Abbas reported having said that the Prophet (SWT) said "Whoever wants to make salaam sale, do so upon specified weight and for a specified duration of time" (narrated by Ibn Abbas as cited in Muhammad et al., 2013). Islamic teachings set some necessary condition for Ordered-Sale. The subject matter of the Ordered-Sale must be precise and specific, capable of being available in the market and delivered in the future. The ownership of the subject matter of an Ordered-Sale goes to the buyer (Ahmad, 2001).

In some cases, one party (i.e. the buyer) requests another party (i.e. workman or seller) to go through an agreement to make a specific subject matter and get the mutually set amount as wage or price once it is made. The subject matter is not in presence, and the price is subject to be paid in future once it is ready to be delivered. Such a contract is allowed in Islam and known as Manufacturing-Sale (Bai' Al-Istisna') (Ahmad, 2001).

There is another contract where both the buyer and seller agree to trade and defer the payment amount for the subject matter. Islam allows such Deferred-Sale (Bai' Muajjal) unless the subject matter is non-existent, the owner does not possess or own it, the sale is pending for a future date rather than instant and absolute sale, the price is uncertain, and sale attaches conditions (Ahmad, 2001).

In respect of e-commerce, it mostly receives the payment of the price in advance for the subject matter. The buyer gets the delivery of the product in the future. This exemplifies Ordered-Sale which is in line with the Islamic teaching. Another sale in e-commerce may establish upon agreement of the buyer and seller that the buyer will pay the set amount as the price or wage when the seller will make ready the item to deliver. As mentioned above, such Manufacturing-Sale is legal in Islam. Furthermore, in e-commerce, it is a very common feature to pay in instalments. When the seller agrees to receive payment in instalments and sells the item to the buyer, it is considered a legal contract of sale. E-commercial sales, therefore, are not contradictory to the Sharia (Islamic law) of contracts and naturally, they are legally binding and admissible as per Sharia.

Additionally, the e-commerce platform may work as a seller or even a broker. As a seller, it works as a separate legal entity from the individuals who establish it (Ayub, 2013). As a broker, it allows outsiders to sell their merchandise. Sharia permits both the acts of the separate legal entity of an e-commerce platform and the brokerage (Al-'Ajluni, 2002). 


\section{Two Common Issues regarding E-Commerce}

The following section covers two important topics of discussion that everyone needs to know while involving in e-commerce. They are significantly existing in the field of e-commerce and make discrepancy. It is worth knowing the status of e-commerce payment that relates the possibility of being attached with interest (riba) which is forbidden for Muslims and the status of data protection which crucial for consumers as they are private, may cause financial loss or similar.

\subsection{The Status of E-Commerce Payment}

In e-commerce, a common issue arises regarding the permissibility of the method of payment. The most useable methods of payment in e-commerce include credit card, electronic cash, electronic cheque, and smart cards based electronic payment System (Amboala et al., 2015). Unless paying via credit card all these methods are permissible in Sharia as they are remote use of cash. They enable an immediate transfer of cash from one account to another. Using these methods do not provide any room for interest (Zainul et al., 2004).

Using a credit card in e-commerce payment associates the possibility of being attached with interest. A credit card system allows the cardholder to borrow a certain amount of money from its issuer. The credit card establishes a loan relationship between the cardholder and the issuer. It sometimes allows the cardholder to return the money advanced with a minimum charging fees, but in most cases, it imposes interest along with other charges i.e. service charge, interchange fee, etc. In case the payment is delayed it continues charges until full payment is settled (Amboala et al., 2015).

A common misconception exists that using credit is permissible if the user pays back the used amount before the due date. For this, the question of Islamicity is in question when the credit card user only pays a minimum required amount (i.e.15\%) and the credit card issuer charges monthly interest for the remaining balance (Hussin, 2002). Islam strictly restricts interest in money advanced. Since the credit card associated with interest, it is impermissible to use a credit card even if the cardholder settles the loan amount throughout the specific time to prevent the interest from being charged (al-Islāmī, 2000).

\subsection{The Status of E-Consumer Protection}

E-commerce users enjoy various features including trading anytime (24/7) from anywhere, less transaction cost, timesaving, avoiding physical move, and easy price and specification comparison. All these features have made an easier way of hassle-free living for many consumers, especially who has time limitation or dislikes dealings crowed. While Sharia appreciates e-commerce, it is worth knowing whether e-commerce is safe in term of consumer data protection.

Scholar opines security is the main problem as there are possibilities of financial losses due to bad sites or seller who aims user's money fraudulently (Nanehkaran, 2013). It is difficult for the e-commerce platform to justify the seller's motive that gives the floor to bad people to misuse the opportunity. Even there is no guarantee for product quality as it may damage during shipment or the real appearance may differ from the advertisement look. In this sense, e-commerce lacks safety for e-consumers (Nanehkaran, 2013). In the case where the claim of refund is allowed and probable maybe with/without terms and condition, there still associate the losses for the consumers i.e. time losses, postage charge, etc.

Privacy and data protection are crucial issues in e-commerce. Besides the growth of ecommerce, these issues have given rise to the growing concern regarding the rights of privacy and data protection of huge e-consumers worldwide. E-consumers expect that their data which has been provided upon submitting or fulfilling the purchasing form will remain confidential. Their information would not be stolen or used by the unauthorized party. They believe an ecommerce platform or system is strong enough to protect from unauthorized access to their information (Zainul et al., 2004). However, it is well identified the law provides a lower-level protection for the e-consumers compare to the conventional methods (Amin \& Nor, 2012). Scholars opine that there are several cases of violence for consumers, including issues relate to security of their records and monetary losses aligned with fake marketing (Areheart, 2007). 
These are the common issues regarding consumer protection in e-commerce that always make e-consumers anxious while they make financial dealing.

\section{CORPORATE SOCIAL RESPONSIBILITY FROM E-COMMERCE PERSPECTIVE}

Corporate social responsibility (CSR) is a concept which implies responsibilities that business must protect and contribute to the society where it runs (Beekun, 1997). Doing business in Islam is considered as religious requirements to Muslims as described earlier (AlShaibani, 1997). In Islam, the concept of brotherhood and social justice give rise to CSR of business (Naqvi, 1981) by sharing prosperity for the improvement of the society (Hassan, 2002). Since business plays a vital role in the social and economic condition of the life of numerous stakeholders including customers, investors, employees etc (Abeng, 1997), CSR became a crucial part of business under Sharia throughout the ages.

E-commerce therefore needs to deploy initiatives that ensure social justice which is the foundation of Islam. It prevents Muslims from doing any harm to others (Yusoff \& Noor, 2002). The Quranic verse exemplifies that "Allah commands justice, the doing of good, and liberality to kith and kin, and He forbids all shameful deeds, and injustice and rebellion..." (Ali, 2016, v. 16:90). Additionally, it needs to consider the concept of brotherhood that makes Muslims responsible to each other (Alhabshi, 1994). Maintaining these two concepts such as social justice and brotherhood can lead e-commerce to a super class CSR practice (Naqvi, 1981) as it is promoted in the Hadith "A Muslim is a brother of another Muslim: he neither wrongs him, nor leaves him without help, nor humiliates him" (Muslim).

The convergence of technology and business prospect has given new complicated levels of Islamic business ethics. It requires the Islamic jurisprudents to enlarge their means of evaluation and analysis outside the conventional perspective (Amboala et al., 2015). Ecommerce has negated many of the constraints of traditional business i.e., style and form of traditional business and due to the massive advantages for human, it is spreading rapidly (Nanehkaran, 2013). However, to comply with Sharia and ensuring social justice and brotherhood that leads to upper class CSR, some rules and obligations of e-commerce need to be aligned with the need of Islamic business principles and acceptable in Islam (Zainul et al., 2004). The following discussion explores some significant part of business activities that every business needs to consider carefully.

Sharia allows every activity of human if they do not contradict the divine guidance given by Allah (SWT). For Muslim, it is the religious duty to perform every action in line with the commands of Almighty Allah (SWT) which turns into acts of virtue due to obedience (Zainul et al., 2004). As mentioned in the Holy Quran "And when the Prayer is finished, then may ye disperse through the land, and seek of the Bounty of Allah: And celebrate the Praises of Allah often (and without stint): That ye may prosper" (Ali, 2016, v. 62:10).

Islam praises business and considers it as a legitimate resource of wealth and beneficial for all. Fairtrade and honest business are advised and strongly encouraged by the Sharia. Such a business refers to maintaining the following five (5) legal parameters in its every activity to achieve socially responsible business honour.

Fardh (required): Mandatory for every Muslim. Fardh includes prayers, fasting during the month of Ramadhan and zakat.

Mustahabb (recommended): Highly recommended, but not obligatory for Muslims. Mustahabb includes supererogatory fasting beyond Ramadhan, praying Nawafil, etc.

Muhab (indifferent): Neither mandatory nor prohibited for Muslim. Muhab includes a personal penchant for one type of Halal (permitted) over another.

Makruh: Not forbidden or prohibited but are detested since doing excess may results in punishment like Haram (prohibited). Makruh is in the lower class to Haram. For instance, smoking is Makruh since it is not explicitly prohibited as alcohol.

Haram (unlawful and prohibited): Strictly prohibited for Muslim. Haram represents a major sin for which strong punishment is granted. 
Maintaining these legal values lead to faithfulness, authenticity, honesty and decency those are the fundamental teaching of Islam. Islamic teaching led Muslims to be very trustworthy, honest and God-fearing in every sort of business or trade-related activity. As stated in the Quran "... Allah hath permitted trade and forbidden usury. Those who after receiving direction from their Lord, desist, shall be pardoned for the past; their case is for Allah (to judge); but those who repeat (the offence) are Companions of the Fire: They will abide therein (forever)" (Ali, 2016, v. 2:275).

Islamic teaching strongly prohibits fraud, lie, and phoney advertisement. In modern ecommerce, tricks are very common and effective tools as they put the customer in a vulnerable position while they are relying on Web information to make it to a buying decision (Zainul et al., 2004). The e-commerce advertiser, for example, is very apt to take advantage of ambiguity, hide facts, overstate and use an emotional approach to convince customers to buy according to their emotive needs rather than reason (Zainul et al., 2004). Such business action is contradictory and goes out of the legal values of Sharia. As stated in the Quran "And O my people! Give just measure and weight, nor withhold from the people the things that are their due: Commit not evil in the land with intent to do mischief" (Ali, 2016, v. 11:85).

Sharia-compliant e-commercial activities must not involve any action which Sharia restricts or prohibits. It must adhere to the contractual obligations according to the Quranic principles. As it says "O ye who believe! Fulfill (all) obligations" (Ali, 2016, v. 5:1). It must avoid false and untrue advertisement and misrepresentation. It must ensure accurate measurement and weights while complying with Quranic commands as "Give full measure when ye measure and weigh with a balance that is straight: That is the most fitting and the most advantageous in the final determination" (Ali, 2016, v. 17:35).

Business under Islam is guided to avoid interest (riba) and unlawful trade as they are strictly prohibited. The Holy Quran mentions "Those who devour usury will not stand except as stands one whom the Evil One by his touch hath driven to madness. That is because they say: "Trade is like usury," but Allah hath permitted trade and forbidden usury. Those who after receiving direction from their Lord, desist, shall be pardoned for the past; their case is for Allah (to judge); but those who repeat (the offence) are Companions of the Fire: They will abide therein (forever)" (Ali, 2016, v. 2:275).

Islamic business principles prohibit hoarding and profiteering as they result in dreadful consequences. It can be exemplified by the consequence where businesspeople hoard key commodities throughout periods of shortage or crisis and wait for higher prices. The common people suffer from such business practice and left with no option unless buying them at a high price. The hadith of the Holy Prophet (SWT) warns about such actions "The one who brings food to the market, Allah will help him, provide well for his family and the one who hoards is cursed by Allah" (narrated by Ibn Majah as cited in Zainul et al., 2004). The responsibility of business under Islam involves no destruction of surplus produce to generate an unnatural shortage of goods and boost the price by unnatural excess in need. Because Islamic teaching prohibits such method of business as the Holy Prophet (SWT) warns "I dislike three things of you: useless argumentation, wasting goods and excessive questioning" (as cited in Zainul et al., 2004).

Responsible e-commerce requires Sharia compliance in its internal activities such as fair recruitment practice, fair treatment of workers, and most significant protection of the environment. Because Sharia compliance refers to every action, internal-external must be in line with the Sharia fundamentals and ethical values. Practising discrimination, nepotism, corruption, bribery, treating workers as machines or tools, providing unfair wages, poor working environment and unsuitable work for the worker demonstrate non-compliance of Sharia. The Holy Quran states "Allah doth command you to render back your Trusts to those to whom they are due; and when ye judge between man and man, that ye judge with justice...." (Ali, 2016, v. 4:58). The Holy Prophet (SWT) said "Give the labourer wages before his perspiration be dry" (as cited in Zainul et al., 2004).

Islamic teaching is absolute and pure as they ensure complete success for mankind in this life and life Hereafter. It can be exemplified by the following hadith that represents 
protection for the overall benefit rather than an individual. "There is no scope for causing damage in Islam neither in the case of independent action nor as a reaction" (as cited in Zainul et al., 2004). Those actions are strictly prohibited and hated in Islam that harm or trigger hassles to the public or society in general. It is, therefore, demanded in this study a good judgment and avoiding prohibited materials and actions to ensure social justice and brotherhood which is the focal point of corporate social responsibility as per Sharia.

\section{Findings: Some E-Commercial Imperative Issues to be Resolved}

Considering e-commerce is in line with the Sharia principles of business, this study finds some unusual issues and limitation of e-commerce which need careful attention. Removing them and upgrading the existing feature of e-commerce may make the e-commerce experience better and safe for all worldwide. There is malpractice that may not be considered as the e-commercial elements but, they are very close to relate Islamic standards. This study hypothetically argues that e-commerce should take initiative for the following irregular issues.

\section{Content Filtering}

In e-commerce, the most important and useful tool is content filtering. It removes unnecessary objects from a larger source of what is sought, leaving a clearer, richer edition of what came before. It is to pass through a device to remove unwanted materials. Each ecommerce platform uses its proprietary method that develops a structure of classifications against which all locations be assessed against. The filtering measures include activating words in the subject-object, IP addresses or other digital indicators found in data packs flowing across the web. The classification and rank system are then applied to create profiles like Children, Adult or Work (Houghton-Jan, 2010).

E-commerce mostly uses such filtering to assist buyers in searching for an item on the platform. In the case of adult materials i.e., sex toy, adult movie, it seeks age confirmation to provide results. Interested buyer provides concern of their age confirmation but in most ecommerce, there is no actual age confirmation valuation. This is because, unless payment for purchasing, there is no requirement for adding details like bank card information, identification card or anything which can verify the competency or the age.

Content filters need to be extremely powerful in protecting and ensuring Sharia compliance. In the case a Muslim buyer performs a search for non-compliance material in the e-commerce platform, it must be blocked to respond. Because otherwise it would be assisting or in some cases abetting the buyer to do something prohibited in the light of Islam. Ecommerce filtering presently employs artificial intelligence, image detection, and complicated keyword assessment algorithms to an exceptionally granular level (Houghton-Jan, 2010). A responsible administrative intervention to identify and create appropriate groups or sites of the contents is urgent. So that only Sharia compliance material will be available for Muslim consumer either by request or automatically. Because for Muslims, it is prohibited to watch or hear or talk or deal with haram materials that may lead to sinful thinking or actions. Allah (SWT) has given faculties and every means of guidance; it is the individual mankind who is responsible for his wrongdoings. If mankind goes wrong, it is because he wrongs himself. The Holy Quran warns that "Verily Allah will not deal unjustly with man in aught: It is man that wrongs his own soul" (Ali, 2016, v. 10:44).

A strict, powerful content filter is urgent since the present filtering cannot effectively assess and verify the authentic content, perspective, and objective of the web content of numerous media types such as script, still pictures, video, audio, and more. Scholars opine that current content filter execution is extremely reliant on the program's artificial intelligence content identification (Houghton-Jan, 2010). This study recommends a safe and strict filtering system, if possible, application of administrative human intervention to ensure Islamic values. So that it will disable both the buyer and seller to deal with the Sharia non-compliance material. It is important to remember the following words that the Holy Quran states "If ye two turns in repentance to Him, your hearts are indeed so inclined; but if ye back up each other against him, truly Allah is his Protector, and Gabriel, and (every) righteous one among those who believe, --and furthermore, the angels-will back (him) up" (Ali, 2016, v. 66:4). 


\section{Data Protection}

A safe e-commerce platform protects subject alteration, timing change, source rejection, and destination denial to guarantee integrity (Stallings, 2006). It ensures zero accidental or malicious alteration or destruction of the data (Abrams \& Joyce, 1995). Any changes to the content of data and information like insertion, deletion, transposition, and modification, or delay or replay them, or any denial of transmission from the source, and/or denial of receipt the by destination may cause due to unauthorized access in between the buyer and seller capable to intercept the data sent in the system (Stallings, 2006). Such unauthorized access may enable not just modification (i.e., quantity) but to replay the same data sending (i.e., to repurchase the same item several times). Thus, the system needs to ensure data protection by securing authorized access only. Since e-commerce is an open market, unauthorized access may probably occur, and e-consumers cannot get any privacy thereon which may lead them to expose to global situations.

There may be a checking technology, which will verify the process against the compliance rules (Gray, 2005). In this respect, Sharia-based e-commerce can deploy the Intermediate Sharia Transaction Party (ISTP) as the intermediary third party to present proof among the parties. A study, namely "Development Method for Shariah-compliant e-commerce Payment Processing" explains, the ISTP is based on the code of ethics that includes the dayto-day business activities corresponding to the pre-defined divine laws (Amboala et al., 2015). It works as the entrusted third party that confirms that the transaction data is protected and there is no possibility of being tampered with. This paper recommends the ISTP approach as a scientific solution.

\section{Conclusion}

It is fair to say the growth of technology has made the most essential and revolutionary change to our lives, which is the evolution of an Internet-based civilization. The means of business using the Internet, networks and other digital tools have fundamentally changed the current of human life. It is a blessing for us where the business processes involve websites in which the merchants or organizations provide necessary info with the profile of the company, product or service. The internet provides broad and free entrance to all the companies listed in the virtual world. It is an admitted fact and permissible way of doing commercial activities over an e-commerce platform. The discussion above exemplified the e-commercial elements, functions and other relevant materials that are in line with the Sharia principles. Muslim's protections and religious obligations are well protected in the e-commerce platform. However, some issues need careful attention for the betterment of the e-commerce experience.

The concept of CSR in Islam refers to the concept of Halal or permitted which means business requires to maintain permissibility of its actions. Halal or permissible business actions leads to the initiatives that protect Muslim's faith and religious obligations. This paper discussed various Haram or prohibited elements of business that everyone needs to avoid. The study also submits a plea for good judgement ensuring CSR through not practicing unethical business practices as discussed. E-commerce platform enjoys the controlling power of the business activities and it has every opportunity to maintain sharia fundamentals for both the buyer and seller. It is therefore expected that e-commerce platform will take initiatives to ensure sharia compliance business. This study focuses that Sharia is not locked up only to Muslim. Anyone, regardless of religion, race or region can practice Sharia. Sharia protects all and maintaining all the Sharia requirements ensure social justice and brotherhood that leads to overall peace and prosperity that is the aim of corporate social responsibility.

\section{Reference}

Abeng, T. (1997). Business ethics in Islamic context: Perspectives of a Muslim business leader. Business Ethics Quarterly, 7(3), 47-54.

Abrams, M. D., \& Joyce, M. V. (1995). Refereed paper: Trusted system concepts. Computers and Security, 14(1), 45-56.

Ahmad, D. D. (2001). The Theory of Riba.

Ahmad, S. F. (1991). The ethical responsibility of business: Islamic principles and implications. Journal of Objective Studies, 3(1), 23-43.

Al-'Ajluni, A. (2002). Al-ta'aqud 'an tariq al-internet. Oman: Maktabah Dar al-Thaqafah.

al-Islāmī, M. A. F. (2000). Resolutions and recommendations of the Council of the Islamic Fiqh 
Academy 1985-2000. Islamic Research and Training Institute Islamic Development Bank.

Al-Momani, B. (2004). Mushkilat al-ta'aqud 'ibra al-internet: Dirasah muqaranaht. Jordan:'Alam Al-Kutub Al-Hadith.

Al-Shaibani, I. (1997). Kitab al-Kasb min Kutub al-Iqtisadi al-Islami. Syria: Maktab A/Matbuah.

Al-Zahrani, A. J. (2009). Ahkam al-tijarah al-iliktroniyyah fi al-fiqh al-Islami. Beirut: Dar AlQalam.

Alhabshi, O. (Ed.). (1994). The role and influence of religion in society. Institute of Islamic Understanding Malaysia.

Ali, A. Y. (2016). The Holy Quran English Translation of The Meanings. Digital Deen Publications (PublishDrive).

Alzaagy, A. (2007). The Islamic concept of meeting place and its application in e-commerce. Masaryk University Journal of Law and Technology, 1(1), 27-42.

Amboala, T., Mokhtar, A. H. A., Muhammad, M. Z., bin Noordin, M. F., \& Othman, R. (2015). Development method for shariah compliant e-commerce payment processing. International Journal of Computer Theory and Engineering, 7(5), 408-415.

Amin, H. (2008). E-business from Islamic perspectives: Prospects and challenges. Journal of Internet Banking and Commerce, 13(3), 1-13.

Amin, N., \& Nor, R. M. (2012). An overview of e-consumer protection in sale of goods contracts in Malaysia. International Conference on Information Society (i-Society 2012), 274-275.

Areheart, B. A. (2007). Regulating cyberbullies through notice-based liability. Available at SSRN 1865988.

Ayub, M. (2013). Understanding islamic finance. Gramedia Pustaka Utama.

Azizan, M. H., \& Wahid, N. A. (n.d.). Business in Islam: A Reviewed Essay. Academia. Edu.

Beekun, R. I. (1997). Islamic business ethics (Issue 2). International Institute of Islamic Thought (IIIT).

Brunn, S. D., \& Leinbach, T. R. (2001). Worlds of E-Commerce: economic, geographical and social dimensions. Wiley.

Esposito, J. L., \& DeLong-Bas, N. J. (2018). Shariah: what everyone needs to know. Oxford University Press.

Gray, T. (2005). Canadian response to the US Sarbanes-Oxley Act of 2002: new directions for corporate governance. Parliamentary Information and Research Service.

Haqqi, A. R. (1999). The philosophy of Islamic law of contract. Kuala Lumpur, Malaysia: Univison Press Sdn Bhd.

Hassan, N. M. N. (2002). Business Social Responsibility from the Islamic Perspectie. Corporate Governance from the Islamic Perspective (S. M. S. S. M. Hassan, N. H. N. and Shaikh Mohd Saifuddeen Shaikh Mohd Salleh (Ed.)). Kuala Lumpur: Institute of Islamic Understanding Malaysia (IKIM).

Houghton-Jan, S. (2010). Internet filtering. Library Technology Reports, 46(8), 25-33.

Hussin, D. H. (2002). E-Commerce: Exploring Some Issues from the Islamic Perspective.

King, D. N., \& King, D. N. (2004). Introduction to e-commerce. Prentice Hall.

Laudon, K. C., \& Laudon, J. P. (2000). Management information systems: organization and technology in the networked enterprise. Prentice Hall International.

Lokmanulhakim, H., Fairooz, A., \& Bahroddin, B. (2012). Analisis Syariah terhadap produkproduk pelaburan emas di Malaysia [Sharia analysis of gold investment products in Malaysia]. 8th Discourse among Members of the Shariah Advisory Council of the Financial Institutions in Malaysia, Putrajaya International Convention Center, 29th May.

Mohammed, N. (1988). Principles of Islamic contract law. Journal of Law and Religion, 6(1), 115-130.

Muhammad, M., Muhammad, M. R., \& Khalil, K. M. (2013). Towards Shari'ah compliant ecommerce transactions: A review of amazon. com. Middle-East Journal of Scientific Research, 15(9), 1229-1236.

Nanehkaran, Y. A. (2013). An Introduction to Electronic Commerce. International Journal of Scientific \& Technology Research, 2(2).

Naqvi, S. N. H. (1981). Ethics and economics: An Islamic synthesis. Islamic foundation.

Rosly, S. A. (2010). Shariah parameters reconsidered. International Journal of Islamic and Middle Eastern Finance and Management.

Patwary, A. K., \& Rashid, B. (2016). The impacts of hospitality services on visit experience and future visit intention of student travelers. International Journal of Business and 
Technopreneurship, 6(8), 107-125.

Patwary, A. K. (2020). Developing a Conceptual Framework on Retailers' Performance Towards Tourists' Shopping Satisfaction. South Asian Journal of Social Sciences \& Humanities, $1(1), 60-67$.

Saleem, M. Y. (2012). Islamic commercial law. John Wiley \& Sons.

Stallings, W. (2006). Cryptography and network security, 4/E. Pearson Education India.

Timmers, P. (2000). Electronic Commerce: Strategies and Models for Business-to-Business Trading John Wiley and Sons. Chichester, UK.

Turban, E., King, D., Lee, J., \& Viehland, D. (2002). Electronic commerce: A managerial perspective 2002. Prentice Hall: ISBN 0, 13(975285), 4.

Whiteley, D. (2000). E-commerce: strategy, technologies and applications.

Yusoff, N. M. A. N., \& Noor, I. (2002). Islam \& Business: Striking a Balance Between Commercialism and Humanitarism, Profit and Social Responsibility. Pelanduk Publications.

Zainul, N., Osman, F., \& Mazlan, S. H. (2004). E-Commerce from an Islamic perspective. Electronic Commerce Research and Applications, 3(3), 280-293.

Zwass, V. (2001). Structure and macro-level impacts of electronic commerce: from technological infrastructure to electronic marketplaces. http://www.mhhe.com/business/mis/zwass/ecpaper.html 